\title{
Features of the legal regulation of seasonal workers employed in agriculture
}

\author{
Anna Kulikova ${ }^{1 *}$, Anna Astashova ${ }^{2}$, and Aleksadr Kvasha $^{3}$ \\ ${ }^{1}$ Institute of Service and Entrepreneurship (Branch) of the Don State Technical University in \\ Shakhty, 147, Shevchenko str., 346500, Shakhty town, Rostov region, Russia
}

\begin{abstract}
The production of agricultural products is a complex, specific and labor-intensive process. Agricultural production depends on a number of climatic and natural factors. The influence of the seasons on the growth of crops determines the nature of work in the agro-industrial complex. In certain seasons, agriculture needs additional labor. These provisions provide for the appearance in the labor legislation of Russia, foreign states and international legal acts of a special category of workers - seasonal workers. The work of seasonal workers has a number of features, one hundred requires special legal regulation. This article analyses the legal regulation of employers' employment relations with seasonal workers in Russian, foreign and international legislation.
\end{abstract}

\section{Introduction}

A feature of agricultural activity is seasonality due to the particularities of product production. In agriculture the demand for labour depends on the time of year and weather.

Agricultural production is a biological process controlled by weather and seasons: the demand for resources depends on the time of year and the sequence of agricultural operations, for example, soil preparation, planting, weeding and harvesting. Seasonal fluctuations in labour demand are common for agriculture in all countries but are particularly pronounced in low-income agricultural countries because of labour-intensive production methods and limited investment in labour-saving technologies [1].

Globally, seasonality particularly affects the extremely poor over 80 per cent of whom live in rural areas [2]. Empirical studies have documented evidence of seasonal labour shortages and underemployment in countries such as China [3], Malawi [4], India [5] and the USA [6]. Seasonal underemployment is the predominant trend in rural areas rather than open unemployment as farmers cannot achieve full employment in non-agricultural activities during periods of lull. [7] Seasonal underemployment is the driving force behind seasonal migration $[8,9]$.

\section{Methodology}

\footnotetext{
* Corresponding author: naukatgp@yandex.ru
} 
The methodological basis of the study is general scientific methods - dialectical, formal logic, analysis and synthesis; private scientific methods - logical-legal, comparative-legal, system-structural, document analysis, analysis of print and electronic publications, statistical methods.

\section{Results of the research}

Agricultural activity is related to the production of various agricultural products: grain and leguminous, technical, tuberous, vegetable, melon crops; production of orchards, vineyards, perennial plantations and floriculture; products of cattle breeding, pig breeding, sheep and goat breeding, poultry breeding, fish breeding, beekeeping, sericulture, etc. The production of these products is associated with certain natural cycles and is possible at specific periods of the year. Seasonality is a distinctive feature of rural livelihoods and especially in agriculture the demand for labor depends on the time of year and weather. The percentage of persons permanently employed in agriculture in Russia is small and is declining annually. (Figure 1)

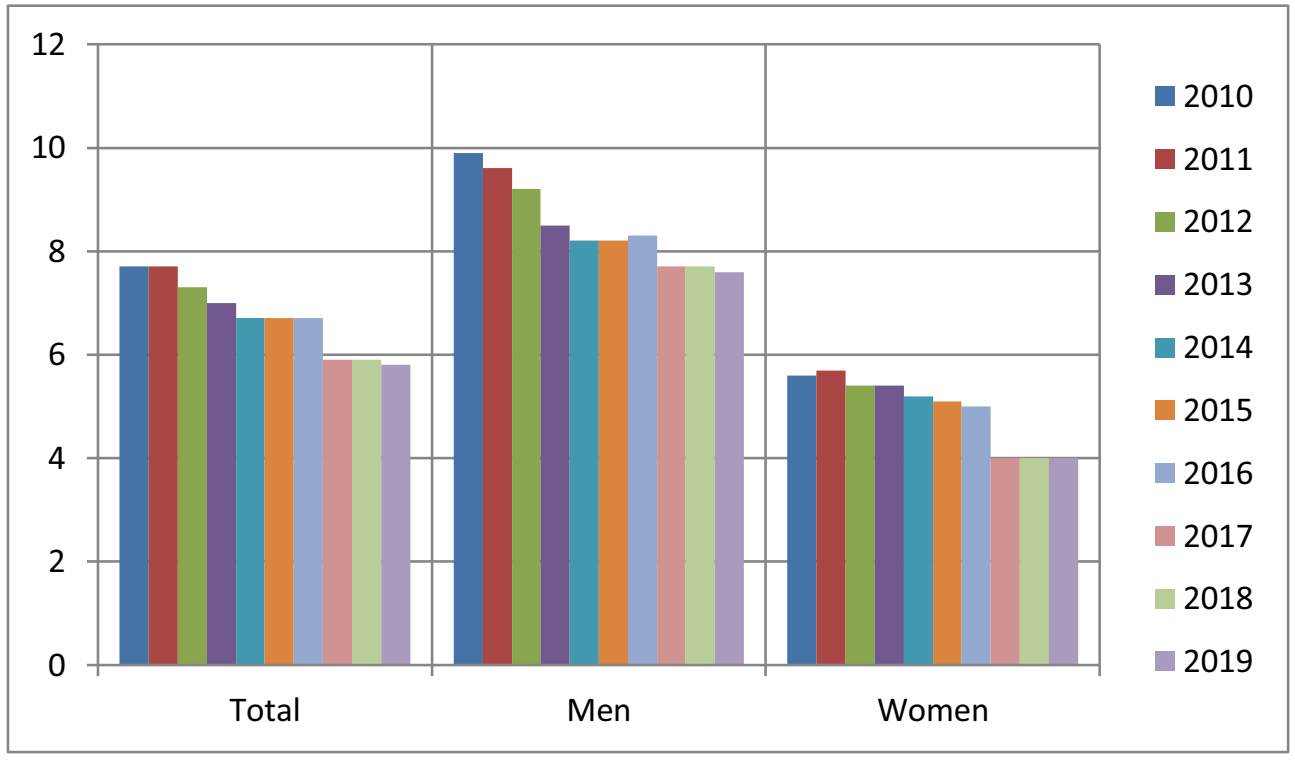

Fig. 1. Information on the number of workers employed in agriculture in Russia.

The legal category "seasonal employee" is in the legislation of Russia, some foreign countries, as well as in international legal acts. In the Russian Federation the legal regulation of seasonal and other employees working on fixed-term and indefinitely concluded labor contracts is differentiated. The labor contract is among the features of the legal regulation of seasonal workers, it is worth noting the term of the labor contract is up to 6 months, as well as the reduced period of notification of the termination of the labor contract with the employee. A positive provision in the Russian legal regulation of seasonal workers is that the calculation of the length of service of seasonal workers is carried out in such a way that the duration in the corresponding calendar year is a full year of work, so the off-season rest of such workers is credited to the length of service.

The problem of providing agricultural labour in developed countries is being addressed by migrant workers involved in seasonal work. As a rule, such migrants come from third world countries. The work of seasonal migrant workers is low-paid and often their rights are violated by employers. In order to protect this category of workers, Directive 
2014/36/EU of the European Parliament and the Council of 26 February 2014 "On conditions of entry and stay of third-country nationals for employment as seasonal workers." The purpose of the instrument was to establish the legal obligations of the participating countries to ensure respect for the rights of seasonal migrant workers.

The labour legislation of foreign countries as a whole also recognizes the equality of the rights of seasonal and other workers but has its own characteristics. For example, in the United States seasonal workers are not covered by the Family and Health Leave Act. In Norway in order to prevent the exploitation of seasonal migrant workers, transitional regulations were established by the Norwegian authorities in 2004. These rules set minimum standards for wage levels (defined by minimum rates in tariff agreements) and working conditions in conjunction with the registration and control of incoming labour. In Canada the law provides that daily overtime for seasonal workers must be paid one and a half times after eight hours of work per day and twice as much after 12 hours of work per day.

\section{Discussion of results}

In Russia seasonal workers are also widely involved in agricultural labor. In accordance with the Labor Code of the Russian Federation seasonal work is a work is temporary and, as a rule, its duration does not exceed six months due to the weather and climate conditions. Russia has a method of centralized management and differentiation for labor law. The differentiation of legal regulation of labour is explained by many objective and subjective factors. One of the objective factors is the peculiarities of weather and climatic conditions which led to the peculiarities of the legal regulation of labor of workers engaged in seasonal work. An important condition for concluding an employment contract with a seasonal employee is the existence of an appropriate indication in it of the seasonal nature of the work.

The urgent and short-term nature of seasonal work affects the duration of employment law. For example, seasonal workers have the right to paid rest, but the period of this leave is calculated depending on the number of months employed in seasonal work - two days of leave for each month worked. When terminating an agreement with a seasonal employee, the employer must warn the employee about this no later than three working days. If the employment contract with the seasonal employee is terminated early due to the liquidation of the organization or a reduction in the number or staff, then in this case the employer is obliged to notify the employee of the dismissal on this basis no later than seven calendar days and pay severance pay in the amount of two weeks' earnings.

These circumstances are due to the specificity of the legal regulation of the labor of employees employed in seasonal work. All other conditions, rights and guarantees apply to such employees on a general basis.

The employment contract with seasonal employees refers to fixed-term employment contracts. The minimum term of an employment contract concluded with a seasonal employee is not defined in the legislation. Fixed-term employment contracts have a number of features of legal regulation compared to employment contracts concluded indefinitely. A prerequisite for an employment contract concluded for a certain period is an indication in it of the dates for the start and end of work. As practice shows, this period can be indicated both by a certain date and by the occurrence of certain consequences. For example, a worker employed for harvesting may be dismissed upon completion of work. With regard to fixed-term employment contracts, the Labor Code of the Russian Federation establishes a rule according to which, if at the end of the term of the contract neither party expresses a desire to terminate it, the contract is considered concluded for an indefinite period. We believe that this rule cannot be applied to contracts concluded with seasonal workers, since 
this is due to the peculiarities of the work for which the employee is hired - after the termination of the conditions defined by the season, the need for such work does not fall.

It would be noted that the Russian Federation Government decree of 04.07.2002 N 498 establishes the rule according to which calculation of seniority of seasonal workers is made so that duration in the corresponding calendar year was full year of work. The calculation of seniority affects the acquisition of the right to an insurance pension. This provision creates a more privileged position for seasonal workers than for other categories of fixedterm workers. In other cases, not related to the performance of seasonal work, work experience is calculated in proportion to the time worked.

For seasonal employees the employer has the right to establish a test condition when concluding an employment contract. Probationary period for employees employed from two to six months may be set for a maximum of two weeks.

The agricultural complex occupies an important place in the economy system and is one of the leading production industries. Therefore, the task of providing employment, attracting workers to the agricultural sector becomes a necessary area of state legal regulation of relations in the field of providing the village with labor resources. The problem of low, unstable employment of agricultural workers forces villagers to move to cities and choose more stable activities and earnings.

The problem of seasonal work in agriculture is manifested in two aspects - on the one hand, the irregular employment of seasonal workers, which affects their earnings and living standards, on the other hand, the outflow of workers from the village to the city in search of stability and wealth, as a result of which the agricultural sector itself suffers from a shortage of personnel during certain periods of production.

As the country develops, the role of agriculture as a local employer decreases. But the broader agri-food system is also expanding and opportunities for agricultural employment go beyond farming. The problem of employment of seasonal agricultural workers is characteristic not only for Russia, but for all countries of the world. Historically, technological revolutions have shaped and been shaped by this dynamic. Today the digital revolution is coming. In this process of structural transformation, societies evolve from a surplus to a shortage of domestic agricultural labor, which is usually compensated by foreign hired agricultural workers. Nevertheless, anti-immigration sentiment has increased sharply in migrant countries, and agricultural production may face these problems [10].

Most often, in developed countries the shortage of agricultural labour was filled mainly by foreign wage-earners, especially when performing tasks difficult to automate, such as harvesting fresh fruit and vegetables. Work in agriculture is usually seasonal and geographically fragmented with productivity often low and unpredictable. High fertility among the rural and agricultural population, partly due to low and volatile incomes in agriculture often contributes to low productivity. As countries grow richer, their demand for non-food goods and services increases and their workforce shifts from agriculture to more stable, better-paid jobs in industry and services.

As an illustration of the problems of labor migration of seasonal workers employed in agriculture, we will give the experience of Norway. EU enlargement in 2004 accelerated economic, political and institutional integration between Western and Eastern European countries. Among the most important changes was the opening of Western European labour markets to citizens from the new member States, which led to an increase in the flow of migrant workers from Eastern Europe to Western Europe. Norwegian farmers were among those most willing to benefit from this new supply of cheap labour, as migrants performed their work in a quality manner and at a low cost. However, a large number of low-paid foreigners have created a number of problems for the Norwegian agricultural sector. In particular, representatives of trade unions and the media accused him of exploiting migratory agricultural workers, who are one of the most vulnerable groups in the labor 
market (the so-called "social dumping"). In response to concerns about farm labour relations, Norway has developed transitional regulations introduced by the Norwegian authorities in 2004 [11]. These rules set minimum standards for wage levels (defined by minimum rates in tariff agreements) and working conditions, combined with the registration and control of incoming labour, and were considered by the Norwegian authorities as an important tool to prevent "social dumping." At the same time, farmers' officials campaigned to monitor farmers' compliance with transitional rules, for example, through media statements emphasizing that good treatment of migrant workers was crucial to the continued political support of agricultural businesses and, consequently, the survival of the agricultural sector as a whole. Interestingly, when the Norwegian authorities decided to terminate the transitional agreements by May 2009, farmers' representatives agreed with trade unions on the need for alternative measures to ensure a minimum level of working conditions. Trade unions have proposed national regulation of the general application of wage agreements, which in effect means that farmers are still obliged to pay migrant workers under tariff agreements, regardless of their union membership. [12]

This example reflects the treatment of agricultural workers by the State and by employer farmers. In response to the situation with regard to the exploitation of migrant workers in agriculture, the State had taken control of the issue by establishing minimum wage requirements and a minimum list of conditions to be met by farmers and employers. On the other hand, farmers, I fear for my reputation, on which state subsidies depend, adopted with approval the developed rules.

In the USA most labor laws with the exception of the Family and Health Leave Act (FMLA) are also applied to seasonal workers. Both the federal Fair Labor Standards Act (FLSA) and state laws require companies to pay their seasonal employees 1.5 times the normal wage rate for any hours worked in excess of 40 during a given work week, just like their regular employees.

With regard to legal and tax regulation, the United States also established uniform rules that apply in general to both seasonal and permanent employees. Employers should be guided by the provisions of the Federal Unemployment Tax Act (FUTA), provide social security, medical care and withhold income tax from the salaries of seasonal employees.

In addition, seasonal workers are entitled to the same legal protection as full-time permanent workers. These include full guarantees of workplace safety, employee compensation, prohibition of labor discrimination, provisions on the amount of overtime pay and other provisions of the federal Fair Labor Standards Act (FLSA), as well as rules established by state labor protection laws. There are no special rules for paying for seasonal work.

In Russia, there is virtually no differentiation in the remuneration of seasonal workers employed in the agricultural sector. The rules for the remuneration of seasonal workers do not differ from the rules for the remuneration of other categories of workers.

In Canada, the British Columbia Employment Standards Act for the most part makes no distinction between seasonal and permanent employees, but there are several important exceptions. In addition, even when the law guarantees equal rights to seasonal and other workers, the nature of seasonal employment can affect the fact that some employers inadvertently violate the rights of seasonal workers.

The main difference between the legal regulation of seasonal and other workers provided for in the Act is the establishment of special obligations of the employer upon dismissal. Article 63 of the Act establishes the amount of compensation in the form of a sum of money proportional to the time worked, which the employer is obliged to pay upon dismissal without reason. However, article 63 does not apply to certain seasonal workers in certain circumstances. As stated in article 63 of the Act, employers are not obliged to provide compensation to seasonal employees who: work for a certain period and know the 
exact date of dismissal at the beginning of work; are hired to perform certain work for a 12month period and know at the time of recruitment that their work will end when the project is completed or by a certain date; or are governed by a collective agreement that specifies the terms and conditions of employment of seasonal staff.

According to article 63 of the Act employers are required to provide notice of dismissal and compensation to seasonal employees if none of the three conditions is met. The provisions of this article apply to cases where an employer hires an employee to perform a certain job but then terminates the job before the job is completed.

It is worth noting that if the period of seasonal employment is not determined by the exact date, but is due to the period of work, but due to weather or other unpredictable conditions, the work cannot be performed, then the employer will be obliged to provide compensation for dismissal in accordance with Art. 63. The law, as soon as it becomes obvious that the work cannot be completed. Most periods of seasonal employment range from 3 to 12 months, in which case the period of notice of dismissal is 1 week. Thus, even if at the beginning of seasonal work it is not possible to determine the exact end date of such work, then at the end of the season it is more likely to determine the end date of work.

With regard to overtime, employers generally have the same obligations to seasonal workers as for long-term employees. This is important to note, since at the peak of the season, employees can be involved in overtime. Briefly, the Act provides that daily overtime shall be paid one and a half times after eight hours of work per day and twice as much after 12 hours of work per day. It is also worth noting that certain groups of seasonal workers (e.g. camp managers) may be subject to other rules on working hours, overtime requirements and minimum wages, as specified in the Employment Standards Regulation.

International legal instruments also contain rules aimed at regulating the work of seasonal workers. Thus, the Directive of the European Parliament and the Council 2014/36/EU of February 26, 2014 "On conditions of entry and stay of third-country citizens for employment as seasonal workers" was adopted in order to promote the effective management of migration flows for a specific category of seasonal temporary migration and to ensure decent working conditions and living conditions for seasonal workers, establishing fair and transparent rules of admission and stay and determining the rights of seasonal workers. The provisions of the directive are based on the principles of equality, freedom of work and choice of type of work. The duration of stay of seasonal migrant workers in accordance with the Directive is 90 days, the maximum period of stay must be established by Member States and is limited to a period of five to nine months, provided that the work is indeed seasonal. It should be envisaged that during this maximum period of stay it is possible to extend the contract or change the employer, provided that the admission criteria are still met. This should reduce the risk of abuse that seasonal workers may face if tied to a single employer while at the same time providing a flexible response to the actual labour needs of employers [13].

The directive stipulates that seasonal workers are workers who live outside the EU and work in the EU for the duration of the season, concluding a fixed-term employment contract. The directive also establishes such a concept as seasonal activity (season), that is, activities that are tied to a certain time of year and are repetitive. During these periods, additional recruitment is needed, as the intensity of production increases. These include, for example, activities such as tourism, agriculture, horticulture and other seasonal activities.

Member States have the right to provide additional guarantees for employees other than those provided for by law, but cannot, for example, change the length of stay or rules of entry. The entry condition of the seasonal employee is the concluded employment contract or current job offer, which sets out the details of the work. In addition, the employee must have a return ticket, sickness insurance (if the employer does not provide this) and confirmation of the rental of housing. A seasonal worker should have enough funds to not 
need and be a threat to public order, and subsequently not join the ranks of illegal migrants. Seasonal workers can work in this kind of work for five to nine months, and then must return to their country. During the period of stay, employees can change the employer. In some cases, the stay may be extended. The Directive established that those seasonal workers who did not violate the legislation establishing the procedure for staying in the country could be invited to work again for seasonal work next year. In this case, a simplified application procedure can be applied, the expedited procedure for its consideration, and priority can be established for previously employed seasonal workers [14].

The Directive guarantees working conditions include wages and dismissal, as well as health and safety requirements in the workplace, applicable to seasonal work in accordance with the law, regulatory or administrative provision and/or universally applicable collective agreements. ILO pays particular attention to the differences in the legal situation of seasonal workers and migrant workers.

The directive provides equality for at least nine specific categories of rights listed in article 23: conditions of employment and work, the right to strike and employment, the right to receive unpaid remuneration, the right to social security in accordance with article 3 of Ordinance 883/2004 (including sickness benefits, maternity benefits, disability benefits, survivors' benefits, etc.), access to public goods and services, seasonal counselling services, services provided by employment offices, education and training, recognition of professional qualifications and tax incentives [15].

\section{Conclusions}

I would like to note that in the world there are different meanings of such a category as seasonal workers in conclusion. This concept directly depends on the level of economic development of the country. The study showed that in more developed countries, migrants from economically disadvantaged states are mainly considered seasonal workers since citizens of these countries refuse to work at seasonal agricultural work. In third world countries where agriculture is a key factor in the economy, the majority of citizens are involved in agricultural seasonal work and there are problems with non-seasonal employment. Developing countries, Russia have a differentiation of the legal regulation of the labor of seasonal workers. It can be concluded that in Russia the legal regulation of the labor of seasonal workers complies with foreign and international legislation. In general seasonal workers are not impaired in their labour and social rights but their work is hard and low-paid. We believe that in order to provide the agricultural sector with a labour force it is necessary to create legal regulation and more attractive conditions for increasing the level of wages.

\section{References}

1. J. Edward Taylor Diane Charlton. Academic Press, London, United Kingdom, 241 (2019)

2. A. Castañeda, D. Doan, D. Newhouse, M.C. Nguyen, H. Uematsu, J.P. Azevedo, World Develop., 101, 250-267 (2018)

3. X. Zhang, J. Yang, S. Wang, China Economic Review, 22 (4), 542-554 (2011)

4. D.N. Reddy, A.A. Reddy, M.C.S. Bantilan, Review of Economic Perspectives, 16, 337-360 (2016)

5. D.N. Reddy, A.A. Reddy, M.C.S. Bantilan, India Rev., 13 (3), 251-273 (2014) 
6. J.E. Taylor, D. Charlton, A. Yúnez-Naude, Applied Economic Perspectives and Policy, 34, 587-598 (2012)

7. S. Bezu, C.B. Barrett, S.T. Holden, World Develop., 40 (8), 1634-1646 (2012)

8. G. Bryan, S. Chowdhury, A.M. Econometrica, 82 (5), 1671-1748 (2014)

9. Arndt Feuerbacher, Scott McDonald, Chencho Dukpa, Harald Grethe, Food Policy, 93, 101875 (2020)

10. L. Christiaensen, Z. Rutledge, J. Edward Taylor, Food Policy Available online 9, 101963 (2020)

11. J.F. Rye, S. Frisvoll, Regelverk, omfang og praktisering Report 5/07 Centre for Rural Research, Trondheim (2007)

12. J. F. Rye, J. Andrzejewska, Journal of Rural Studies, 26 (1), 41-51 (2010)

13. Directive 2014/36/EU of the European Parliament and of the Council of 26 February 2014 «On the conditions of entry and stay of third-country nationals for the purpose of employment as seasonal workers» // URL: http://eur-lex.europa.eu/legalcontent/EN/TXT/?uri=CELEX:32014L0036

14. World Bank World Development Indicators Dataset, Washington DC, USA (2019) // URL: http://data.worldbank.org/data-catalog/world-development-indicators

15. J. E.Taylor, D.Charlton. The Farm Labor Problem, A Global Perspective, 121-154 (2019) 